\title{
Study on Promotion of Folklore Ecotourism to the Economic Development of Minority Areas in Southeast Chongqing
}

\author{
-Taking Wulong District as an Example
}

\author{
Zihan $\mathrm{Yu} *$ \\ Chongqing Nankai Secondary School \\ Chongqing, China \\ *Corresponding author: 328778702@qq.com
}

\author{
Liyue $\mathrm{Xu}$ \\ School of Economics \\ Huazhong University of Science \& Technology \\ Wuhan, China
}

\begin{abstract}
The minority areas of Southeast Chongqing are primarily located at Wuling Mountain Chain and part of the Wujiang river basin. It is the settlement of various minority groups mainly consisting of Tujia and Miao minority groups while it remains as the National Poverty Regions. However, The Wulong District, southeast Chongqing, holds the potential for Folk Ecological Tourism thanks to its distinctive Karst Landscape. This paper engages in the research of the folk culture, folk cus toms, regional culture, ecological tourism resource, and tourism's promotions on the economic developments in Wulong District. Meanwhile, this article proposes the measures that can potentially be implemented to drive the tourism industry even further, such as ecological fitness tourism, heritage tourism, cultural experience tourism, creating various national festival activities. This paper proposes new ideas for promoting tourism development and speeding up the economic development in Wulong district.
\end{abstract}

Keywords-folk culture; folk ecological tourism; economic development; minority nationality areas; southeast Chongqing

\section{INTRODUCTION}

Wulong District is situated at the downstream of Wujiang River, Southeast Chongqing, which is the joint part of Wuling and Dalou Mountain with Pengshui county to the east, Daozhen County in Guizhou Province to the south, Nanchuan District and Fuling District to the west, and Fengdu conunty to the north. It is full of deep hills, river valley and hilly areas. Its terrain covers $7 / 10$ mountains, $1 / 10$ water and 2/10 fields. The terrain is high in the northeast and low in the southwest. Wujiang River runs across the border from east to west, flowing through sixteen villages and towns. ${ }^{[1,4]}$ It starts from Mumu River in the east and reaches Daxi River in the west, with a journey of 80 kilometers. The tributaries of Mumu River, Furong River, Changtu River, Qingshui River, Shiliang River and Daxi River are transferred from the north and south wings to Wujiang River. The Tongluo Mountain and the Fairy Mountain in the north of the Wujiang River belong to the Wuling Mountain System; the Baima Mountain and the Pinus Mountain in the south of the Wujiang River belong to the Dagu Mountain System. The highest peak of the Fairy Mountain, Modao Bay, is 2033 meters above sea level, and the lowest
Daxi River mouth is 160 meters above sea level. The relative height is generally between 700 meters and 1000 meters. In addition to a few flat dams in the mountains and river valleys, most of them are sloping fields where the soil is mostly yellow soil, yellow brown soil, followed by purple soil. The ethnic minorities are mainly Tujia and Miao, and their settlements are national key ecological functional areas and important biodiversity conservation areas. For a long time, the south of Chongqing and the north of Guizhou have relied on Wujiang River as the sole water transport to the Yangtze River, or through the official road to the east of the Tang Dynasty Road. Thus, Wulong was granted the name of "Tuenmen Screen". ${ }^{[4]}$

\section{FOLK CULTURE AND ECOTOURISM RESOURCES IN WULONG}

\section{A. Folk customs and regional culture of Wulong}

People's diet is primarily based on rice and corn, but they also eat Buckwheat, sorghum, red glutinous rice, artichoke, sweat potato, and potato. There is a common practice of drinking wines and tea. Food specialties include Wujiang fish, bowl of mutton, and dumpling chicken soup. The building is dominated by the Kawasumi Han people's residence style with a "patio" courtyard, as well as Tujia hanging towers and drycolumn houses, among which the Miao Village, Rhinoceros Village and Haokou Tianjiazhai have many national characteristics. For a long time, due to the remoteness of the terrain and inconvenient transportation, especially in the vast rural areas, the Etiquette and custom of the life, death and marriage still maintains a lot of originalities--the custom of giving birth to baby is to have a good news, a meal, and a full moon wine and marriage is usually carried out according to the "six rituals", namely: Nacai, questioning, Najib, Nazheng, Jiayu, and pro-welcome. The Funeral customs of Tujia, Miao and Han in Wulong are basically the same, and they are buried in Burial. Festival customs: Wulong, like other parts of China, attaches great importance to traditional festivals, and maintains the custom of the Spring Festival, the 15th Lantern Festival, the Qingming Festival, the Dragon Boat Festival, and the MidAutumn Festival. Besides that, The Miao nationality has had a "March 3" treading festival, and the Tujia people have had 
special customs such as the "June 6" clothes festival. "Catch a temple" fair is also an important custom of Wulong people.

Wulong has many cultural relics, such as Han Dynasty Tombs, ridges and merchants ruins, Fenglai Dashishi Shilin Temple, Temple Phoenix Village, Baiyun Academy, Jiangkou Li Jinshi's hometown stone carving, Chang Sun Wuji Tomb. Although Wulong is dominated by the Han nationality, it is home to 12 ethnic minorities such as Miao, Tujia and Yi.

All ethnic groups intermarry and exchange cultures, forming a rich and diverse folk culture. Wulong's folk music is divided into two major categories: songs and instrumental music. The songs mainly include mountain songs, crying songs, and filial songs; its form can be divided into labor folk songs, life songs and folk songs. The labor folk songs mainly include sedge songs, boatman horns, masonry horns, and "lift workers". The genre songs mainly include filial piety, crying marry songs and so on. The songs of life mainly include children's songs, nursery rhymes, and so on. Folk music mainly includes waist drums, leaf flutes, gongs and drums, and cymbals. Among them, 'Dong Ping Blowing", 'Pu Ping Ping Song", "Ya Ping blow", "Hou Ping folk song", "Xianlv mountain town playing drum" are listed as Intangible cultural heritage in Chongqing. Folk dances are also rich and varied, including dragon dance, lion dance, car lights, running dry boats, lanterns, flails, bamboo lanterns, stilts, cymbals, drums, carols, swinging dances, etc.

\section{B. Wulong's Ecotourism Resources}

Wulong is one of the few regions in the country that has three gold medals in the world: "World Natural Heritage", "National 5A Tourist Attractions" and "National Tourism Resort”. Bai Juyi, a famous poet of the Tang Dynasty, wrote such a verse in the face of the beautiful Wulong Wujiang River. "After the rain, even the sky is clear, and the autumn is clear." The scholar of the Qing Dynasty, Wen Ruomei, praised the landscape of Wulong, 'this is the first place in the mountains and rivers." Wulong scenic spots include Shan (Fairy Mountain, Baima Mountain), Water (Wujiang, Furong River), Forest (White Horse Mountain Primitive Forest), Cave (Furong Cave), Wetland (Huangyu Wetland Park), Shilin (Dolomite Forest, Fairy Mountain) Stone Forest), Lake (Fairy Lake, Furong Lake), Grassland (Fairy Mountain Prairie) and other rich natural landscapes, with all types of landscapes except the sea and desert, known as the "World Karst Nature Museum". The scenic spots that have been developed include: the world's largest and highest beaded natural bridge groups - Three Natureal Bridges, geological wonders - Longshuixia geosuture, mountain city summer palace, eastern Switzerland and Eden in the mortal world - fairies Mountain National Forest Park, China's only cave listed in the World Heritage List - Furong Cave; water karst forest - Furong River. Touring spots still under development include: subtropical "biological gene pool" - Baima Mountain; the largest tiankeng in the world's mouth area - Zhongshiyuan Tiankeng. Not yet developed: the world's only erosion-type tiankeng - Houping Tiankeng; the world's largest and Asia's deepest shaft group - the star vertical shaft group; Asia's longest cave - Tongluo Mountain cave group; domestic rare Cluster drifting - Mu Brown River, Huangbaidu drifting; water park - Furong Lake; and more than 260 landscapes in the beaded Bubbling Wulong.

\section{Thoughts on the Development of Wulong FolK ECO- TOURISM}

\section{A. Promotion of Tourism to Wulong's Economic Development}

As the development of Wulong tourism continues, the popularity of Wulong specialty is also higher. As shown in Figure 1, In the 10 years from 2008 to 2017, the number of tourist receptions in the Wulong district increased from 2200 thousand to 28 million with an average annual increase of $32.66 \%$.

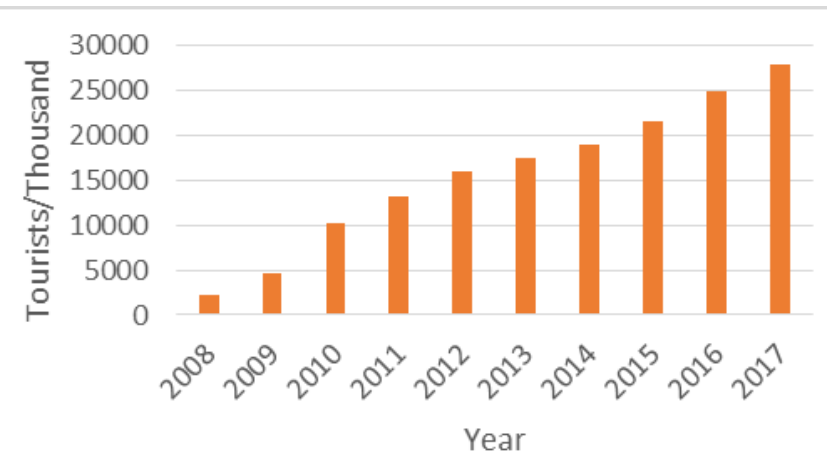

Fig. 1. Nu mber of tourists coming to Wulong in the last 10 years from 2008 to 2017

When visiting foreign tourists are learning about Wulong culture and watching "Impression Wulong", croissants, dried croissants, oysters and Wulong pigs are also well known. These specialties have formed another landscape. The development of flavored catering and the combination of tourism commodities and agriculture have brought about a certain degree of growth in Wulong's economy. The catering industry related to tourism has also been greatly developed, and the development of the primary industry has been promoted, and the degree of commercialization has been improved. The data shows that the contribution rate of tourism consumption to the lodging industry exceeds $90 \%$, the contribution rate to the transportation industry such as roads and railways exceeds $80 \%$, and the contribution rate to the catering and commodity industries exceeds $40 \%$. Wulong belongs to the subtropical monsoon climate, but the average temperature in the town of Fairy Mountain in summer is 20 degrees. It has a natural refreshing cool breeze. It is a good summer resort; many tourists bring their families to the summer to bond with their families while they are happy to spend the summer here. The real estate industry related to this has also achieved tremendous development. While the tourism industry is developing, many people have more employment opportunities and increased employment rates. ${ }^{[2-3]}$

In the 20 years of hard work, Wulong's unemployment rate has been declining year by year, and the unemployment rate has dropped from $4.23 \%$ in 2005 to $1.2 \%$ in 2016 . The number of unemployed people is getting less and less, thanks to tourism and a series of urban construction. Wulong District successfully passed the inspection and acceptance of the 
National Poverty Alleviation Office, and removed the cap of poverty in 2017.

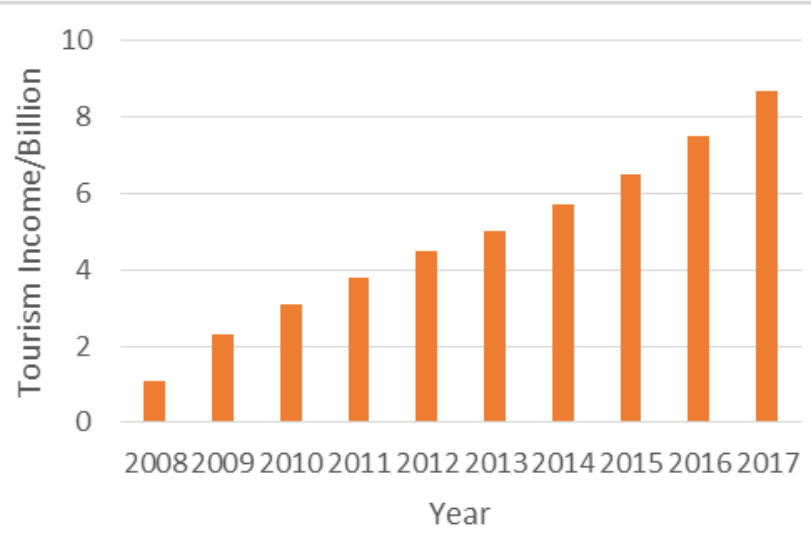

Fig. 2. Tourism income in Wulong District in the last 10 years from 2008 to 2017

With the increase in the number of tourists coming to Wulong, tourism income received 8.7 billion yuan in 2017. As shown in Figure 2, In the 10 years from 2008 to 2017, the tourism income in the Wulong district increased from 1.1 billion yuan to 8.7 billion yuan with an average annual increase of $25.83 \%$.

In 2017, Wulong district goverment proposed the strategy of "green rising, enriching the people and prospering the district", and the economic, political, cultural, social, ecological civilization and party building were promoted in an integrated manner. "Internationally renowned tourist destinations, ecoindustrial economically strong areas, ecological civilization demonstration zones, and landscape garden tourism new cities" have achieved the goal of building a well-off society in an allround way and laid a solid foundation for the construction of "China Wulong National Park". According to the "one heart, one belt, four districts and one network" global tourism layout (one heart: the center of the city built a tourist reception center and tourist distribution center. One area: to build Wujiang Gallery tourism economic belt. Four districts: Xiannvshan District Construction International Tourism Resort, Baimashan Area Construction Forest health tourism resort, Furongjiang area to build a hydrophilic tourist resort, Houping area to build an international adventure sports area. One network: built a rural tourism network covering the whole area), the five major strategies of the whole people's travel and international brands are to create a "two districts and one place" as a carrier (a global tourism demonstration zone, a national tourism reform and innovation pioneer zone, an international karst tourism destination). ${ }^{[5-6]}$

\section{B. Enrich The Tourism Industry.}

- The first is ecological fitness tourism. The government will vigorously develop outdoor recreational sports and speed up the construction of the International Subalpine Transport Base on Mount Fairy, making it the top demonstration base for Eco-sports tourism in China. Eco-sports tourism should be developed on the premise of strictly abiding by the national land policy and ensuring the protection of basic farmland. Taking the international mountain outdoor sports open competition as the carrier, Wulong will accelerate the construction of the best mountain outdoor sports base in China. It will vigorously develop equestrian sports in the fairy mountain new area and actively develop the folk Jockey Club. Development and construction of water sports base of Wujiang, Furong River and Furong Lake will be speed up.

- The second is heritage tourism. Give full play to the advantages of landscape resources of Karst World Natural Heritage in Wulong, and speed up the upgrading on the premise of strict protection. It will speed up the comprehensive development of Huangbaidu drifting and Muzhang River drifting, and start the construction of Tiankeng, Baima Mountain, Xiannu Lake, Wanfeng Linhai, Temple Ping, Qimen Cave Grand Canyon, Yajiang Small Three Gorges and other scenic spots.

- The third is cultural experience tourism. Taking advantage of the unique landform of the main gully of Zhongshi Academy, Wulong invited top international teams to create a high level of "Impression Wulong" large-scale landscape performance, and strive to be incorporated into the city's key tourism and cultural projects. Wulong will also accelerate the creation of an ecological creative park with cultural creativity, entertainment and business incubation. ${ }^{[7]}$

- The last is to focus on creating various national festival activities, such as the Miao nationality's March 3rd Treading Festival, the Tujia's "June 6th" Clothes Festival, and the "June 19th" Festival. National festival activities, branding or large projects drive tourism to alleviate poverty, and it is easier to show results and image.

\section{CONCLUSION}

By analyzing the folk customs, regional culture and ecotourism resources in Wulong District, this paper studies the promotion of tourism to Wulong's economic development, and proposes new ideas for promoting Wulong tourism development, in order to promote Wulong to become a national key ecological function, and it has laid the foundation for important biodiversity conservation areas, ecological folk culture tourism belts and poverty alleviation and development demonstration zones.

\section{ACKNOWLEDGMENT}

The authors thank Chongqing Research Program of Basic Research and Frontier Technology (Grant No. CSTC2015jcyjA40017).

\section{REFERENCES}

[1] Sun Y.Y., "Study on tourism poverty alleviation and performance in southeast Chongqing [D],” Industrial and Commercial University of Chongqing, 2017. 
[2] Liu R., "The ways from rags to riches for the nationality area in the southeast of Chongqing by developing nationality folk-custom tour [J]," Commercial Research, vol.2, 2009, pp.158-161.

[3] Pan M. H., Qiu L., Wang L., "Driving effects of tourism on economic development in five functional areas of chongqing[J]," Journal of Southwest China Normal University, vol.42, No.4, 2017,pp.88-93.

[4] Statistical bulletin, "Statistical Communique of National Economic and Social Development of Wulong District” in 2008-2017. http://wl.cq.gov.cn.

[5] Deng, T., Mulan, M. and Shuai, S., "Research note: has international tourism promoted economic growth in China? A panel threshold regression approach[J]," Tourism Economics, vol. 20, No. 4, 2014,pp.911-917.

[6] Belloumi, M. "The relationship between tourism receipts, real effective exchange rate and economic growth in Tunisia [J]," International Journal of Tourism Research, vol.12, 2010, pp. 550-560.

[7] Chen Y.J., Xu C.R., "An empirical study on the relationship between tourism development and regional economic growth in putian city [J]," Mathematics in Practice and Theory, vol. 46, No.10, 2016:pp.10-15.. 